\title{
ENHANCING THE USE OF INTERNET BANKING IN AN EMERGING MARKET
}

\author{
Jacques Nel \\ Department of Business Management, University of the Free State \\ Christo Boshoff \\ Department of Business Management, University of Stellenbosch \\ Accepted: May 2014
}

\begin{abstract}
Electronic banking services such as internet banking offer bank clients substantial benefits over traditional banking channels. Although internet banking has been around for many years, increasing the use of the service by bank clients remains a priority for many managers of internet banking services. To address this managerial concern, the study investigates the factors that contribute to the enhanced use of internet banking by bank clients. Based on a literature review, internet-banking factors that could influence bank clients' actual use of internet banking were identified. Data were collected from 1156 users of internet banking. The results of the study showed that two factors influence internet banking usage, namely internet banking facilitating conditions and internet banking risk beliefs. The more favourable internet banking facilitating conditions are perceived to be, the more likely bank clients are to increase their use of internet banking. On the other hand, the greater the perceived risks associated with internet banking, the less the chances are that clients will do their banking through the internet. On the basis of these results, recommendations are provided to enhance the use of internet banking.
\end{abstract}

Key words: internet banking, actual use, high and low users, logistic regression analysis, risk, facilitating conditions

JEL: M39

\section{1}

\section{Introduction}

Internet banking is one of several self-service channels that banks offer to their clients to conduct their banking transactions. Internet banking is an electronic banking system that allows clients to perform a wide range of banking transactions electronically via the bank's website, by using a computer and modem to connect to the internet (Tan \& Teo, 2000). Since the introduction of internet banking, it has evolved to provide clients with a full range of services. These days internet banking users can pay accounts online, do balance enquiries, draw account statements, pay tax online, manage investments and do online share trading, apply online for loans and buy pre-paid services.

To date, very little research has been done on the adoption of internet banking. In the limited scholarly research that has been done, scant attention has been paid to the factors that influence actual usage of internet banking. Although the initial adoption of information technology (IT) is important, the success of information technology depends largely on actual usage, as infrequent and ineffective usage of the IT (in this study the internet banking service of a particular bank) after initial adoption may incur undesirable costs or result in a waste of resources (Hong, Thong $\&$ Tam, 2006). Therefore, considering the important part that actual usage of internet banking plays in its success from a bank's perspective, the objective of this study is to identify internet-banking factors that play a role in bank clients' becoming high users of internet banking.

The rest of the article is organised as follows. The theoretical basis for the study is provided in the next section, followed by a 
review of the literature that guided the hypotheses in the study. Next, the research method followed in the study is outlined. This is followed by a discussion of the results of the study. The article concludes with a discussion of the managerial implications emanating from the study and the limitations of the study.

\section{2}

\section{Theoretical basis}

Why would some bank clients make more use of internet banking than others? A plausible answer to this question is that those bank clients who make more use of internet banking than others may perceive internet banking to be the more rational choice for doing banking transactions, compared to other modes of banking. According to Satz and Ferejohn (1994), a rational choice or action is one in which the agent chooses the best available option, given his/her preferences or beliefs. Rational choice theory further holds that the choices a person makes tend to maximise total utility, where utility is synonymous with the modern concept of reinforcement in behavioural psychology (Herrnstein, 1990). Because utility cannot be directly observed, it must be inferred from behaviour, which is exemplified by the choices individuals make. Rational choice theory also holds that individuals must anticipate the outcomes of alternative courses of action and calculate which action will be best for them. Rational individuals choose the alternative that is likely to give them the greatest satisfaction (Scott, 2000).

Consumers are frequently driven by rational choice in decision-making (Schmitt, 1999). Therefore, as rational decision makers, they value functional features and benefits when evaluating different choices. Shafir, Simonson and Tversky (1993) argue that it is natural in decision making to select an option because of its positive features, and to reject an option because of its negative features. By evaluating the pros and cons of choices, individuals search for a convincing rationale for their decisions. When they make a choice, the positive features associated with the choice will loom larger. In rejecting a choice, individuals give more weight to its negative features. Consumers' search for a convincing rationale to justify their choice may be motivated by interpersonal considerations so that they can explain to others the reasons for the decision. On the other hand, the search for a convincing rationale could be prompted by intrapersonal motives, where the decision maker may need to feel confident of having made the "right" choice. Thus, in the context of the study and in accordance with technology acceptance theory, the rational choice of bank clients to use internet banking ought to be guided by their rationalisation of the benefits and risks related to the use of internet banking. In addition, an internet banking user's perception of the ease and difficulty of performing internet banking transactions could also influence his/her use of internet banking.

Taking the four broad factors that could influence the rational choice of a bank client to use internet banking as the basis, a series of hypotheses were developed and empirically tested in this study. Hypotheses were firstly generated to explore the influence of timesaving, convenience and ease of use benefits of internet banking on the rate of use of internet banking (section 3.1). As risk perceptions may decrease the rate of use of internet banking and given the importance of trust in internet banking to mitigate risk perceptions (Yousafzai, Pallister \& Foxall, 2009), we also formulated hypotheses to assess the influence of risk and trust on internet banking rate of use (section 3.2). Lastly, to investigate an internet banking user's perception of ease and difficulty in performing internet banking transactions, hypotheses related to the influence of facilitating conditions and self-efficacy on internet banking rate of use were proposed (section 3.3).

\section{3}

\section{Development of hypotheses}

\subsection{Benefits of internet banking and the rate of use of internet banking}

One of the most widely utilised models for information technology user acceptance and usage is the Technology Acceptance Model (TAM) (Venkatesh \& Morris, 2000; Tseng, Chien-Lung \& Yu-Hao, 2012). TAM suggests that two specific factors - perceived ease of use and perceived usefulness - determine a 
user's behavioural intention to use a technology (Venkatesh, 2000). Perceived usefulness can be described as "the degree to which a person believes that using a particular technology will enhance his [or her] performance" (Sun \& Zhang, 2006). Usefulness is also considered to be related to the extrinsic motivation construct in motivational theory (Teo, Lim \& Lai, 1999; Venkatesh, Speier \& Morris, 2002). Extrinsic motivation is a construct that refers to an activity executed in order to realise separate outcomes. Extrinsic motivation therefore differs from intrinsic motivation, which refers to doing an activity simply for the enjoyment of the activity itself, rather than for its instrumental value (Ryan \& Deci, 2000). The primary benefit of internet banking for most bank clients is probably the convenience it offers (Lassar, Manolis \& Lassar, 2005). Another benefit that is strongly associated with the usefulness of ubiquitous electronic services such as internet banking is time saving (Pagani, 2004). On the other hand, perceived ease of use refers to "the extent to which a person believes that using a techno$\operatorname{logy}$ will be free of effort". Financial institutions also present ease of use as a benefit of internet banking (see ABSA, 2012 and Standard Bank 2012). Perceived ease of use refers to user motivation, which is based on the assessment of the intrinsic aspects of using information technology (Gefen \& Straub, 2000). Perceived ease of use is therefore a construct tied to an individual's assessment of the effort involved in the process of using the system (Venkatesh, 2000).

According to rational choice theory, internetbanking users who perceive internet banking to offer the benefits of convenience, time saving and ease of use will use it more frequently. Research by Pikkarainen, Pikkarainen, Karjaluoto and Pahnila (2004) shows that perceptions of usefulness have a positive influence on the use of internet banking. Thus, it can be argued that perceptions of convenience and time saving influence the actual use of internet banking. Although Pikkarainen et al. (2004) do not find a significant positive relationship between ease of use and the frequency of use of internet banking, other research such as that of Igbaria, Iivari and Maragahh (1995) does provide empirical evidence of a positive relationship between ease and frequency of use of information technology. The following hypotheses were therefore formulated for the study:

H1. Bank clients are more likely to become high users of internet banking than low users as their convenience perceptions of internet banking increase.

H2. Bank clients are more likely to become high users of internet banking than low users as their time-saving perceptions of internet banking increase.

H3. Bank clients are more likely to become high users of internet banking than low users as their ease-of-use perceptions of internet banking increase.

\subsection{Risk and trust, and the rate of use of internet banking}

Users of internet banking are exposed to performance risk, social risk, time-loss risk, privacy risk (Aldás-Manzano, Lassala-Navarré, Ruiz-Mafé \& Sanz-Blas, 2009) and financial risk (Kuisma, Laukkanen \& Hiltunen, 2007). For example, internet banking users may experience performance risk when the bank's front-end or back-end systems do not function properly. They may also be exposed to timeloss risk owing to the slow loading of pages and difficulty in navigation (McCole, Ramsey \& Williams, 2010).

Internet banking users may lose money while performing transactions or transferring money over the internet (Kuisma et al., 2007). Financial risk for internet banking users is magnified because internet banking transactions lack the assurance provided in traditional settings through formal proceedings and receipts. Therefore, clients often experience difficulties when they apply to be compensated for transaction errors (Kuisma et al., 2007). If consumers perceive some risk in using an electronic service, this reduces the usefulness of the service (Gefen, Karahanna \& Straub, 2003; Lu, Hsu \& Hsu, 2005). Not only do risk perceptions reduce the usefulness perceptions of an electronic service; they can also reduce the extent to which the service is used (McCloskey, 2003). Hence, it is reasonable to argue that the stronger the perception on the part of bank clients that internet banking is risky, the less likely they are to see it as the rational choice. 
Consequently, they will use internet banking less frequently for banking transactions. The following hypothesis is therefore considered:

H4. Bank clients are more likely to become low users of internet banking than high users as their risk perceptions of internet banking increase.

Trust is not only a central part of successful business relationships and transactions, but also a key factor in online commerce. Trust beliefs can be described as the confident trustor perception that the trustee has attributes that are beneficial to the trustor (McKnight, Choudhury \& Kacmar, 2002). Although many types of belief can be identified from the literature, three types of trust belief come to the fore: competence, benevolence and integrity (Gefen et al., 2003; McKnight et al., 2002; Zhang \& Zhang, 2005; Zhao, Koenig-Lewis, Hanmer-Lloyd \& Ward, 2010). In the context of this study, competence can be operationalised as the client's belief that the bank has the required infrastructure and processes in place to deliver the promised internet banking services. Benevolence can be operationalised as the client's belief that the bank will deliver the internet banking services in a way that is in the best interests of the client. Lastly, integrity can be seen as the client's belief that the bank will deliver the internet banking service as promised. Perceptions around trust play an important role in the use of internet banking (Herrnstein, 1990). Trust has a positive influence on beliefs regarding the usefulness of internet banking and these influence actual use (Eriksson, Kerem \& Nilsson, 2005). The following hypothesis regarding rational choice theory was therefore addressed:

H5. Bank clients are more likely to become high users of internet banking than low users as their trust perceptions of internet banking increase.

\subsection{Control beliefs and the rate of use of internet banking}

According to Bandura (1977), efficacy expectations play a very important role in affecting behaviour. Efficacy expectations form part of perceived behavioural control in the Decomposed Theory of Planned Behaviour (Taylor \& Todd, 1995). Bandura (1977) describes an efficacy expectation as a conviction that one can successfully execute the behaviour required to produce the outcomes. In the context of this study, internet banking self-efficacy focuses on self-efficacy at the task/application level and can be operationalised as the bank client's perception of efficacy in using the internet banking service to manage his/her personal finances. According to Hill, Smith and Mann (1987), self-efficacy plays an important role in the use of information technology. Therefore, based on rational choice theory, it can be argued that the higher the bank client's internet banking efficacy expectations are, the more use he/she would make of internet banking. The following hypothesis is thus addressed in the study:

H6. Bank clients are more likely to become high users of internet banking than low users as their internet banking self-efficacy perceptions increase.

The Decomposed Theory of Planned Behaviour also proposes that facilitating conditions (a component of perceived behavioural control) are an important construct to consider in technology adoption behaviour. Facilitating conditions relate to the external resource constraints of the control beliefs structure, and self-efficacy refers to an internal control belief (Taylor \& Todd, 1995). Taylor and Todd (1995) point out that the facilitating conditions construct provides two dimensions for control beliefs. The first dimension relates to resource factors such as time and money, and the second dimension relates to technology compatibility issues that may constrain usage. According to Venkatesh, Brown, Maruping and Bala (2008), system use is contingent on the consideration of whether, and to what extent, an individual perceives that facilitating conditions will enable system use in the light of other potential behaviour impediments. Furthermore, Venkatesh, Thong and Xu (2012) confirm empirically that facilitating conditions have a positive influence on the use of information technology. Thus, it can be argued that enhanced internet banking facilitating conditions favour internet banking as the rational choice for banking transactions, which gives rise to the following hypothesis:

H7. Bank clients are more likely to become high users of internet banking than low users as their perceptions of internet banking facilitating conditions improve. 
4

\section{Methodology}

\subsection{Target population and sampling}

The target population for this study was bank clients aged 18 years and over who use internet banking. Given the constraint of bank clients' privacy rights, a sampling frame could not be obtained from any bank. Thus, a nonprobability, convenience sampling method was adopted. Invitations to participate in the survey were posted on major online e-commerce sites, on the Facebook alumni page of the university at which one of the researchers was employed, and in e-mail newsletters to the alumni. The main advantage of using different survey distribution points was that they extended the reach of the survey. Eventually, after checking that all the questionnaires received had been correctly completed and eliminating all double submissions, data from a sample of 1156 users of internet banking were available for analysis.

\subsection{Data collection}

In the absence of a sampling frame and taking into consideration the sampling criterion that all respondents must be users of internet banking, the most appropriate method of collecting data was an online questionnaire. The advantages of internet surveys include low cost, fast turnaround time, high geographical reach, and fast distribution (Forrest, 1999).

\subsection{Measurement}

Scales from previous studies were used, and modifications to the scales were made, where necessary, to reflect the context of the study. Respondents' beliefs about internet banking were measured on a 7-point Likert scale ( $1=$ strongly disagree; $7=$ strongly agree), except for internet banking risk perceptions, which were measured with the aid of a semanticdifferential scale $(1=$ not at all risky, $7=$ very risky). The items used to measure internet banking beliefs are presented in Appendix 1.

\subsection{Data analysis}

Descriptive data were analysed using SPSS 21.0. To test the stated hypotheses, a logistic regression analysis was conducted, also using SPSS 21.0. Logistic regression analysis was the appropriate statistical technique to use, because the outcome variable "type of internet banking user" is binary (high users of internet banking and low users). To divide the sample of internet banking users into high and low users, the k-means cluster algorithm in SPSS 21.0 was used to cluster the sample into high and low users of internet banking, based on their self-reported use of internet banking for banking transactions. By using the k-means clustering algorithm to divide the sample, rather than an arbitrary method, it was ensured that the fundamental assumption of logistic regression, namely that the categories are mutually exclusive, was met. Once the two clusters had been developed, the measurement theory in each cohort was assessed for construct validity by means of a confirmatory factor analysis using EQS 6.2. In addition to the assessment of construct validity, the measurement models were also assessed for factorial invariance across the two clusters.

\section{5}

\section{Results}

\subsection{Descriptive results}

The results in Table 1 indicate that of the 909 high users of internet banking, 379 were males and 530 females. Of the 247 low users of internet banking, 111 were males and 136 females. The respondents in both cohorts also represented various age groups (see Table 1). In both clusters, the age categories 21-30 and 31-40 cumulatively represented more than 60 per cent of the respondents. Furthermore, both clusters also included respondents 51 years of age and older, making the sample of high and low users more representative of the general population of bank clients.

Table 2 reports the bank affiliation of the respondents. About 31 per cent of the respondents were Absa clients, about 23 per cent were Standard Bank clients, 11.5 per cent were Nedbank clients, 29.68 per cent were FNB clients and 3.74 per cent were Capitec clients. A small number of respondents were clients of other financial institutions such as Chase, Bidvest and Investec. The number of responses in Table 2 adds up to more than 1156 , as some of the respondents are clients of more than one bank. 
Table 1

Demographic information on the respondents

\begin{tabular}{|l|c|c|c|c|r|}
\hline \multicolumn{2}{|c|}{ Demographics } & \multicolumn{2}{c|}{ High users } & \multicolumn{2}{c|}{ Low users } \\
\cline { 2 - 6 } & & $\mathbf{n}$ & $\mathbf{n} \%$ & $\mathbf{n}$ & $\mathbf{n} \%$ \\
\hline \multirow{3}{*}{ Gender } & Male & 379 & 41.7 & 111 & 44.9 \\
\cline { 2 - 6 } & Female & 530 & 58.3 & 136 & 55.1 \\
\hline \multirow{4}{*}{ Age } & $18-20$ & 10 & 1.1 & 4 & 1.6 \\
\cline { 2 - 6 } & $21-30$ & 333 & 36.6 & 122 & 49.4 \\
\hline & $31-40$ & 297 & 32.7 & 79 & 32.0 \\
\cline { 2 - 6 } & $41-50$ & 167 & 18.4 & 20 & 8.1 \\
\cline { 2 - 6 } & $51+$ & 102 & 11.2 & 22 & 8.9 \\
\hline
\end{tabular}

Table 2

Bank affiliation

\begin{tabular}{|l|c|c|}
\hline \multicolumn{1}{|c|}{ Bank } & $\mathbf{n}$ & $\mathbf{n \%}$ \\
\hline Absa & 443 & 30.72 \\
\hline Standard Bank & 326 & 22.61 \\
\hline Nedbank & 167 & 11.58 \\
\hline FNB & 428 & 29.68 \\
\hline Capitec & 54 & 3.74 \\
\hline Other & 24 & 1.66 \\
\hline Total & 1442 & 100 \\
\hline
\end{tabular}

Table 3 presents information on the use of internet banking by the high users and the low users. The high users pay 81 per cent of their accounts by means of internet banking and do the majority of their cash transfers, balance enquiries and the drawing of account statements by means of internet banking. In contrast, the low users pay less that 50 per cent of their accounts by internet banking, while using internet banking for about 50 per cent of balance enquiries and the drawing of account statements during a typical month. The results in Table 3 also show that the low users use internet banking for approximately 66 per cent of cash transfers. The results of the t-test in the last column in Table 3 indicate that the use of internet banking for the four banking transactions differs across the two clusters.

Table 3

Use of internet banking

\begin{tabular}{|l|c|c|c|}
\hline \multirow{2}{*}{ Banking transactions } & \multicolumn{2}{|c|}{$\begin{array}{c}\text { Monthly use of internet banking for } \\
\text { banking transactions } \\
(\%)\end{array}$} & $\begin{array}{c}\text { Independent } \\
\text { sample t-test }\end{array}$ \\
\cline { 2 - 4 } & High users & Low users & $\rho<.000$ \\
\hline Paying of accounts & 81.0 & 48.2 & $\rho<.000$ \\
\hline Cash transfers & 97.6 & 65.7 & $\rho<.000$ \\
\hline Account balance enquiries & 93.4 & 50.6 & $\rho<.000$ \\
\hline Drawing of statements & 95.8 & 50.0 & \\
\hline
\end{tabular}

\subsection{Assessment of the measurement models}

Before the logistic regression analysis was conducted, the psychometric properties of the measurement model were assessed with the data for each cohort. This was done by conducting a confirmatory factor analysis (CFA) using the computer program EQS 6.2. Before considering the validity of the measurement model using model fit indices, the construct validity of the measurement theory in each cluster was examined by 
assessing convergent validity and discriminant validity (Hair, Black, Babin \& Anderson, 2010). To meet the criteria of convergent validity, the factor loadings in each measurement model should be significant, namely 0.50 or higher, and ideally 0.70 or higher (Hair et al., 2010). In addition, the average variance extracted (AVE) percentage should be 0.5 or higher and the construct reliability (CR) value of each latent variable should be 0.70 or higher to indicate adequate convergence or internal consistency (Hair et al., 2010). The method proposed by Fornell and Larcker (1981) was adopted to assess discriminant validity in each measurement model. This method entails comparing the average variance extracted for each construct with the shared variance between constructs. For evidence of discriminant validity, the average variance extracted for both constructs must be higher than the shared variance between the two constructs.

The results in Table 4 show that the items in each cluster load above 0.5 on the intended factor, while only two items in each cluster have a loading of lower than the ideal of 0.7. Furthermore, the CR value and the AVE of each construct in Table 4 are above the recommended values, as suggested in Hair et al. (2010). It can therefore be concluded that the measurement model of each cohort exhibits adequate convergent validity.

Table 4

Assessment of convergent validity in both cohorts

\begin{tabular}{|c|c|c|c|c|c|c|c|}
\hline \multirow{2}{*}{ Construct } & \multirow{2}{*}{ ITEM } & \multicolumn{3}{|c|}{ High users } & \multicolumn{3}{|c|}{ Low users } \\
\hline & & sw & CR & AVE & sw & CR & AVE \\
\hline \multirow{4}{*}{ Internet banking ease of use (IBEOU) } & IBEOU1 & 0.836 & \multirow{4}{*}{0.905} & \multirow{4}{*}{0.707} & 0.822 & \multirow{4}{*}{0.894} & \multirow{4}{*}{0.678} \\
\hline & IBEOU2 & 0.698 & & & 0.799 & & \\
\hline & IBEOU3 & 0.904 & & & 0.895 & & \\
\hline & IBEOU4 & 0.908 & & & 0.773 & & \\
\hline \multirow{4}{*}{ Internet banking trust (IBT) } & IBT1 & 0.741 & \multirow{4}{*}{0.900} & \multirow{4}{*}{0.693} & 0.77 & \multirow{4}{*}{0.851} & \multirow{4}{*}{0.589} \\
\hline & IBT2 & 0.851 & & & 0.772 & & \\
\hline & IBT3 & 0.846 & & & 0.736 & & \\
\hline & IBT4 & 0.886 & & & 0.79 & & \\
\hline \multirow{4}{*}{ Internet banking convenience (IBCON) } & IBCON1 & 0.911 & \multirow{4}{*}{0.913} & \multirow{4}{*}{0.726} & 0.916 & \multirow{4}{*}{0.927} & \multirow{4}{*}{0.763} \\
\hline & IBCON2 & 0.888 & & & 0.927 & & \\
\hline & IBCON3 & 0.871 & & & 0.882 & & \\
\hline & IBCON4 & 0.725 & & & 0.758 & & \\
\hline \multirow{5}{*}{ Internet banking time saving (IBTS) } & IBTS1 & 0.781 & \multirow{5}{*}{0.922} & \multirow{5}{*}{0.703} & 0.774 & \multirow{5}{*}{0.931} & \multirow{5}{*}{0.730} \\
\hline & IBTS2 & 0.831 & & & 0.813 & & \\
\hline & IBTS3 & 0.871 & & & 0.887 & & \\
\hline & IBTS4 & 0.823 & & & 0.888 & & \\
\hline & IBTS5 & 0.881 & & & 0.903 & & \\
\hline \multirow{4}{*}{ Internet banking self-efficacy (IBSE) } & IBSE1 & 0.907 & \multirow{4}{*}{0.911} & \multirow{4}{*}{0.720} & 0.844 & \multirow{4}{*}{0.903} & \multirow{4}{*}{0.702} \\
\hline & IBSE2 & 0.893 & & & 0.907 & & \\
\hline & IBSE3 & 0.851 & & & 0.864 & & \\
\hline & IBSE4 & 0.732 & & & 0.725 & & \\
\hline \multirow{3}{*}{$\begin{array}{l}\text { Internet banking facilitating conditions } \\
\text { (IBFC) }\end{array}$} & IBFC1 & 0.732 & & & 0.674 & & \\
\hline & IBFC2 & 0.856 & 0.790 & 0.559 & 0.805 & 0.749 & 0.501 \\
\hline & IBFC3 & 0.64 & & & 0.634 & & \\
\hline & IBR1 & 0.92 & & & 0.926 & & \\
\hline 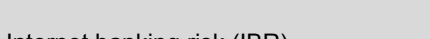 & IBR2 & 0.914 & 0 & 0000 & 0.924 & 0 & 005 \\
\hline Internet bankIng riSK (IBR) & IBR3 & 0.895 & 0.954 & 0.838 & 0.934 & 0.959 & 0.855 \\
\hline & IBR4 & 0.932 & & & 0.915 & & \\
\hline
\end{tabular}


The comparison in Table 5 shows that for each pair of constructs in the high users' measurement model, the AVE of the two constructs is higher than the shared variance (squared correlation) between the two constructs. However, in the low users' measurement model, the squared correlation between IBCON and IBTS is slightly higher than the AVE of IBCON and IBTS (see Table 6).

To provide more rigorous evidence that IBCON and IBTS are indeed two unique constructs in the low users' measurement model, a Chi-square difference test between an unconstrained CFA model of the two constructs and a nested CFA model was done where the correlation between the two constructs is constrained to unity (Bagozzi \& Phillips, 1982). The model fit of the more constrained model was worse than that of the less constrained model. Furthermore, the scaled $\Delta \chi 2$ was significant $(15.319,1 d f)$. Thus, it can be concluded that the two constructs are indeed two unique constructs.

Table 5

Comparison of average variance extracted and squared correlations in the high users' measurement model

\begin{tabular}{|l|c|c|c|c|c|c|c|}
\cline { 2 - 8 } \multicolumn{1}{l|}{} & IBEOU & IBT & IBCON & IBTS & IBSE & IBFC & IBR \\
\hline IBEOU & 0.707 & & & & & \\
\hline IBT & 0.195 & 0.693 & & & & & \\
\hline IBCON & 0.268 & 0.168 & 0.726 & & & & \\
\hline IBTS & 0.280 & 0.172 & 0.699 & 0.703 & & & \\
\hline IBSE & 0.407 & 0.236 & 0.297 & 0.356 & 0.720 & & \\
\hline IBFC & 0.234 & 0.194 & 0.433 & 0.419 & 0.297 & 0.559 & \\
\hline IBR & 0.064 & 0.223 & 0.016 & 0.013 & 0.076 & 0.040 & 0.838 \\
\hline
\end{tabular}

Note: AVE in italics above the diagonal and squared correlations below the diagonal

Table 6

Comparison of average variance extracted and squared correlations in the low users' measurement model

\begin{tabular}{|l|c|c|c|c|c|c|c|}
\cline { 2 - 8 } \multicolumn{1}{l|}{} & IBEOU & IBT & IBCON & IBTS & IBSE & IBFC & IBR \\
\hline IBEOU & 0.678 & & & & & & \\
\hline IBT & 0.377 & 0.589 & & & & & \\
\hline IBCON & 0.249 & 0.170 & 0.763 & & & & \\
\hline IBTS & 0.233 & 0.132 & 0.789 & 0.730 & & & \\
\hline IBSE & 0.377 & 0.360 & 0.381 & 0.419 & 0.702 & & \\
\hline IBFC & 0.262 & 0.160 & 0.539 & 0.619 & 0.372 & 0.501 & \\
\hline IBR & 0.099 & 0.238 & 0.015 & 0.003 & 0.085 & 0.009 & 0.855 \\
\hline
\end{tabular}

Note: AVE in italics above the diagonal and squared correlations below the diagonal

Given that sufficient evidence of convergent and discriminant validity has been established, the model fit indices of the two measurement models can be evaluated. In both measurement models the S-B $\chi 2 /$ df was below 3.0, the CFIs above 0.9 and the RMSEAs well below 0.08 , suggesting a close-fitting model (see Table 7).

Table 7

Model fit of measurement models

\begin{tabular}{|l|c|c|}
\hline \multicolumn{1}{|c|}{ Model fit indices } & High users & Low users \\
\hline S-BX2 & 646.582 & 402.389 \\
\hline $\mathrm{df}$ & 329 & 329 \\
\hline $\mathrm{X}^{2} / d f$ & 1.965 & 1.223 \\
\hline $\mathrm{CFI}$ & 0.907 & 0.934 \\
\hline RMSEA & 0.033 & 0.030 \\
\hline
\end{tabular}


The results presented here indicate that the measurement model in each cohort presents sufficient evidence of construct validity. In addition, factorial invariance (equal measurement models) was also established.

\subsection{Comparison of internet banking factors across the two clusters}

The results of the independent sample t-test in Table 8 show that the means of the factors convenience, time saving, ease of use, selfefficacy and facilitating conditions are higher for high users than for low users. But, as expected, the mean for the internet banking risk factor was found to be higher for low users than for high users. Furthermore, no significant difference was found between the means of the two clusters for the trust factor. However, if one takes into account the argument in the literature review that high users of internet banking should exhibit higher trust beliefs than low users, the difference between the two means is significant $(\rho=.039$, one-tailed $)$.

Table 8

Results of independent sample t-test

\begin{tabular}{|c|c|c|c|c|}
\hline Internet banking factors & Category of users & $\mathbf{n}$ & Mean & $\begin{array}{c}\text { Independent sample } \\
\text { t-test } \\
\text { Sig. (two-tailed) }\end{array}$ \\
\hline \multirow{2}{*}{ Convenience } & High users & 909 & 6.6645 & \multirow{2}{*}{.000} \\
\hline & Low users & 247 & 6.5061 & \\
\hline \multirow{2}{*}{ Time saving } & High users & 909 & 6.7131 & \multirow{2}{*}{.000} \\
\hline & Low users & 247 & 6.5903 & \\
\hline \multirow{2}{*}{ Ease of use } & High users & 909 & 6.3696 & \multirow{2}{*}{.018} \\
\hline & Low users & 247 & 6.2500 & \\
\hline \multirow{2}{*}{ Trust } & High users & 909 & 5.9840 & \multirow{2}{*}{.078} \\
\hline & Low users & 247 & 5.8735 & \\
\hline \multirow{2}{*}{ Risk } & High users & 909 & 3.0039 & \multirow{2}{*}{.025} \\
\hline & Low users & 247 & 3.2338 & \\
\hline \multirow{2}{*}{ Self-efficacy } & High users & 909 & 6.3561 & \multirow{2}{*}{.006} \\
\hline & Low users & 247 & 6.2011 & \\
\hline \multirow{2}{*}{ Facilitating conditions } & High users & 909 & 6.4488 & \multirow{2}{*}{.000} \\
\hline & Low users & 247 & 6.2348 & \\
\hline
\end{tabular}

\subsection{Results of the logistic regression analysis}

Age, gender, use of cell phone banking, the number of monthly accounts payable, cash transfers, bank balance enquiries and account statements drawn were included in the logistic regression model as control variables. In the logistic regression model, low users were the reference category (in other words, low users = 0 and high users $=1$ ).

To assess the model fit of the logistic regression model, various model diagnostics were inspected. Firstly, the classification error rates in Step 0 and Step 1 were compared. In Step 0 (a model that only included the constant), the overall correctly predicted percentage was 21.4 per cent. In Step 1 (a model that includes the constant and the predictor variables) the percentage predicted correctly increased to 60.1 per cent. Furthermore, the model Chi-square of $56.489(\mathrm{df}=14)$ is significant. The significant model Chisquare indicates that the model has a poor fit compared to the model that contains only the constant and that the predictors in the model essentially create a new model. The secondlast model diagnostic considered was the Hosmer-Lemeshow test. The $\rho$-value for the Hosmer-Lemeshow goodness-of-fit test was 0.646, indicating that the model prediction does not differ significantly from the observed values. The last model diagnostic that was used to assess model fit was a ROC curve analysis. In this analysis, the power of the model's predicted values to discriminate between positive and negative cases is 
quantified by the area under the ROC curve (AUC). The AUC, sometimes referred to as the c-statistic (or concordance index), is a value that varies from 0.5 (discriminating power no better than chance) to 1.0 (perfect discriminating power). The AUC was 0.652 and significant $(\rho=.000)$, indicating that the model is able to distinguish between the two outcomes (high user and low user of internet banking). Taking into account the discussion on model fit presented up to this point, it may be concluded that the model demonstrates acceptable fit with the data.

Of the control variables included in the model, only age and the use of cell phone banking were significant. A one-unit increase in age increases the odds that an internet banking user will become a high user by 1.8 per cent. This result can be explained by positive significant correlations between age and the average number of monthly accounts paid, cash transfers, bank balance enquiries and account statements drawn by respondents.
As the age of bank clients increases they do more banking transactions in a typical month, and the utility of internet banking becomes higher. On the other hand, the use of cell phone banking would increase the odds by 40 per cent that a bank client would become a low user of internet banking. This result is understandable, as cell phone banking is an alternative channel for conducting banking transactions.

The results of the hypotheses testing are summarised in Table 9. The results in Table 9 show that only H5 and $\mathrm{H} 7$ were accepted. The results for $\mathrm{H} 5$ and $\mathrm{H} 7$ are interpreted as follows. A one-unit increase in the risk perceptions of an internet banking user would increase the odds by 10.4 per cent that he/she would become a low user of internet banking (H5). Conversely, a one-unit increase in an internet banking user's perceptions of facilitating conditions would increase the odds by 31.6 per cent that he/she would become a high user of internet banking $(\mathrm{H} 7)$.

Table 9

Results of hypotheses testing

\begin{tabular}{|c|l|r|r|r|r|r|r|}
\hline Hypotheses & \multicolumn{1}{|c|}{ Factors } & B & \multicolumn{1}{|c|}{ S.E. } & Wald & df & $\begin{array}{c}\text { Sig. } \\
\text { (one-tailed) }\end{array}$ & Exp(B) \\
\hline 1 & Convenience & .263 & .225 & 1.359 & 1 & .122 & 1.300 \\
\hline 2 & Time saving & -.017 & .261 & .004 & 1 & .474 & .983 \\
\hline 3 & Ease of use & -.044 & .137 & .103 & 1 & .374 & .957 \\
\hline 4 & Risk & -.110 & .061 & 3.246 & 1 & .036 & .896 \\
\hline 5 & Trust & -.084 & .110 & .582 & 1 & .223 & .920 \\
\hline 6 & Self-efficacy & .077 & .133 & .334 & 1 & .282 & 1.080 \\
\hline 7 & Facilitating conditions & .274 & .129 & 4.526 & 1 & .017 & 1.316 \\
\hline
\end{tabular}

\section{6}

\section{Discussion}

The purpose of the study was to determine why certain bank clients use internet banking more than others do. To address the objective of the study, data were collected from 1156 users of internet banking and a logistic regression analysis was conducted to establish which internet banking factors increase/ decrease the odds that a bank client will become a high user of internet banking.

Preliminary analysis of the data showed that high users experience higher internet banking convenience, time saving, ease of use, trust, self-efficacy and facilitating conditions beliefs than low users. On the other hand, low users experience higher internet banking risk beliefs than high users. These results are in line with the discussion in section 3. However, the results of the logistic regression analysis showed that only risk beliefs and facilitating conditions significantly decrease and increase the odds that a bank client would become a high user of internet banking. The negative influence of risk perceptions on internet banking rate of use supports the finding of McCloskey (2003) that risk perceptions negatively influence the use of electronic services. Bank clients who perceive internet 
banking to be more risky are likely to use it less. As discussed in the literature review, risk perceptions decrease the usefulness (value) of an electronic service. It is therefore understandable that higher risk perceptions would lead to a lower use of internet banking. The results also show that bank clients with higher facilitating conditions are more likely to be high users. Enhanced facilitating conditions decrease external resource constraints that can impede the actual use of internet banking. The positive influence of internet banking facilitating conditions on the rate of use of internet banking is consistent with the findings of Venkatesh et al. (2012).

\section{7}

\section{Managerial implications}

On the basis of the results of the study, the following recommendations can be offered to enhance the use of internet banking. Facilitating conditions refer to external resource constraints influencing the use of a technology. In the context of facilitating conditions, banks can only influence access to the internet on computers, which is an important determinant of internet banking use. To increase access to the internet by computer, banks could offer special deals on laptops and data packages/ bundles. If low users are provided with easier access to the internet, the use of internet banking should increase. Secondly, to increase the use of internet banking, managers must mitigate the risk perceptions related to the use of this mode of banking. This can be achieved by educating internet banking users on the risks associated with the use of internet banking and the ways of avoiding these risks. For example, bank clients should be informed regarding the risks related to the use of public computers for internet banking and the internet banking features that should be used when doing internet banking on a public computer. Another example is creating awareness of phishing scams. Awareness on the part of bank clients would make them more confident that they will be able to identify phishing scams and not become the victims of these scams. Banks should also make users aware of existing and new security features on their respective internet banking service. In addition to creating awareness of the security features, banks should educate bank clients on how to use the features.

\section{8}

\section{Limitations of the study}

A potential limitation of the study is that the clusters were only derived from the overall average use of internet banking in a typical month. This procedure provides a narrow basis for clustering. In future, the use of internet banking for different types of transactions could form the basis for clustering internet banking clients into high and low users. This would provide a more precise basis for clustering, namely different individual uses of internet banking rather than an average rate of use.

In the study only two types of internet banking users were considered, namely high users and low users. To advance our knowledge of factors influencing the actual use of internet banking, researchers could make use of a multinomial logistic regression analysis in future and investigate why users are low users, moderate users and high users of internet banking.

\section{9 \\ Conclusion}

What is important for managers is not only the continued use of internet banking by bank clients, but also the actual form this use takes. As far as managers of internet banking services are concerned, bank clients should use internet banking for as much of their banking transactions as possible. By addressing internet banking risk perceptions and providing favourable external conditions for the use of internet banking, managers can provide the necessary enabling conditions for bank clients to increase their use of internet banking. Not only will increased usage make the internet-banking channel more profitable, but enhanced use of internet banking can lead to bank clients experiencing superior service and higher levels of satisfaction through their use of the internet banking service. 


\section{References}

ABSA. 2012. Internet banking. Available at: http://www.absa.co.za/Absacoza/Individual/Ways-toBank/Anytime\%2C-Anywhere/Internet-Banking [accessed 2012-08-23].

ALDÁS-MANZANO, J., LASSALA-NAVARRÉ, C., RUIZ-MAFÉ, C. \& SANZ-BLAS, S. 2009. The role of consumer innovativeness and perceived risk in online banking usage. International Journal of Bank Marketing, 27(1):53-75.

BAGOZZI, R.P. \& PHILLIPS, L.W. 1982. Representing and testing organizational theories: A holistic construal. Administrative Science Quarterly, 27(3):459-489.

BANDURA, A. 1977. Self-efficacy: Toward a unifying theory of behavioral change. Psychological Review, 84(2):191-215.

DAVIS, F.D. 1989. Perceived usefulness, perceived ease of use, and user acceptance of information technology. MIS Quarterly, 13(3):319-340.

ERIKSSON, K., KEREM, K. \& NILSSON, D. 2005. Customer acceptance of internet banking in Estonia. International Journal of Bank Marketing, 23(2):200-216.

FEATHERMAN, M.S. \& PAVLOU, P.A. 2003. Predicting e-services adoption: A perceived risk facets perspective. International Journal of Human-Computer Studies, 59(4):451-474.

FORNELL, C. \& LARCKER, D.F. 1981. Evaluating structural equation models with unobservable variables and measurement error. Journal of Marketing Research, 18(1):39-50.

FORREST, E. 1999. Internet marketing research. Sydney:Irwin/McGraw-Hill.

GEFEN, D., KARAHANNA, E. \& STRAUB, D.W. 2003. Inexperience and experience with online stores: The importance of TAM and trust. IEEE Transactions on Engineering Management, 50(3):307-321.

GEFEN, D. \& STRAUB, D. 2000. The relative importance of perceived ease of use in IS adoption: A study of e-commerce adoption. Journal of the Association for Information Systems, 1(8):1-28.

GU, J.-C., LEE, S.-C. \& SUH, Y.-H. 2009. Determinants of behavioral intention to mobile banking. Expert Systems with Applications, 36(9):11605-11616.

HAIR, J.F., BLACK, W.C., BABIN, B.J. \& ANDERSON, R.E. 2010. Multivariate data analysis: A global perspective. Englewood Cliffs, NJ: Pearson Prentice Hall.

HERRNSTEIN, R.J. 1990. Rational choice theory: Necessary but not sufficient. American Psychologist, 45(3):356-367.

HILL, T., SMITH, N.D. \& MANN, M.F. 1987. Role of efficacy expectations in predicting the decision to use advanced technologies: The case of computers. Journal of Applied Psychology, 72(2):307-313.

HONG, S., THONG, J.Y.L. \& TAM, K.Y. 2006. Understanding continued information technology usage behavior: A comparison of three models in the context of mobile internet. Decision Support Systems, 42(3): 1819-1834.

IGBARIA, M., IIVARI, J. \& MARAGAHH, H. 1995. Why do individuals use computer technology? A Finnish case study. Information \& Management, 29(5):227-238.

KIM, K.K., PRABHAKAR, B. \& PARK, S.K. 2009. Trust, perceived risk, and trusting behavior in Internet banking. Asia Pacific Journal of Information Systems, 19(3):1-23.

KUISMA, T., LAUKKANEN, T. \& HILTUNEN, M. 2007. Mapping the reasons for resistance to Internet banking: A means-end approach. International Journal of Information Management, 27(2):75-85.

LASSAR, W.M., MANOLIS, C. \& LASSAR, S.S. 2005. The relationship between consumer innovativeness, personal characteristics, and online banking adoption. International Journal of Bank Marketing, 23(2): 176-199.

LEE, K.C. \& CHUNG, N. 2009. Understanding factors affecting trust in and satisfaction with mobile banking in Korea: A modified DeLone and McLean's model perspective. Interacting with Computers, 21(5-6):358392.

LEE, M.-C. 2009. Factors influencing the adoption of internet banking: An integration of TAM and TPB with perceived risk and perceived benefit. Electronic Commerce Research and Applications, 8(3):130-141.

LIAO, Z. \& CHEUNG, M.T. 2002. Internet-based e-banking and consumer attitudes: An empirical study. Information \& Management, 39(4):283-295. 
LU, H.-P., HSU, C.-L. \& HSU, H.-Y. 2005. An empirical study of the effect of perceived risk upon the intention to use online applications. Information Management \& Computer Security, 13(2):106-120.

MCCLOSKEY, D. 2003. Evaluating electronic commerce acceptance with the Technology Acceptance Model. Information Technology and Organizations: Trends, Issues, Challenges and Solutions, Winter:49-57.

MCCOLE, P., RAMSEY, E. \& WILLIAMS, J. 2010. Trust considerations on attitudes towards online purchasing: The moderating effect of privacy and security concerns. Journal of Business Research, 63(910):1018-1024.

MCKNIGHT, D.H., CHOUDHURY, V. \& KACMAR, C. 2002. Developing and validating trust measures for e-commerce: An integrative typology. Information Systems Research, 13(3): 334-359.

PAGANI, M. 2004. Determinants of adoption of third generation mobile multimedia services. Journal of Interactive Marketing, 18(3):46-59.

PIKKARAINEN, T., PIKKARAINEN, K., KARJALUOTO, H. \& PAHNILA, S. 2004. Consumer acceptance of online banking: An extension of the Technology Acceptance Model. Internet research, 14(3):224-235.

RYAN, R.M. \& DECI, E.L. 2000. Intrinsic and extrinsic motivations: Classic definitions and new directions. Contemporary Educational Psychology, 25(1):54-67.

SATZ, D. \& FEREJOHN, J. 1994. Rational choice and social theory. The Journal of Philosophy, 91(2):7187.

SCHMITT, B. 1999. Experiential marketing. Journal of Marketing Management, 15(1-3):53-67.

SCOTT, J. 2000. Rational choice theory. Understanding contemporary society: Theories of the present, 126138.

SHAFIR, E., SIMONSON, I. \& TVERSKY, A. 1993. Reason-based choice. Cognition, 49(1):11-36.

SHIH, Y.-Y. \& FANG, K. 2004. The use of a decomposed theory of planned behavior to study internet banking in Taiwan. Internet Research, 14(3):213-223.

STANDARD BANK. 2012. Internet banking. Available at: http://www.standardbank.co.za/portal/site/ standardbank/menuitem.de435aa54d374eb6fcb695665c9006a0/?vgnextoid=5542f8bc8f35b210VgnVCM100 000c509600aRCRD [accessed 2012-08-23].

SUN, H. \& ZHANG, P. 2006. The role of moderating factors in user technology acceptance. International Journal of Human-Computer Studies, 64(2):53-78.

TAN, M. \& TEO, T.S.H. 2000. Factors influencing the adoption of internet banking. Journal of the Association for Information Systems, 1:1-42.

TAYLOR, S. \& TODD, P.A. 1995. Understanding information technology usage: A test of competing models. Information Systems Research, 6(2):144-176.

TEO, T.S.H., LIM, V.K.G. \& LAI, R.Y.C. 1999. Intrinsic and extrinsic motivation in Internet usage. Omega, 27(1):25-37.

TORKZADEH, G. \& VAN DYKE, T.P. 2002. Effects of training on internet self-efficacy and computer attitudes. Computers in Human Behavior, 18(5):479-494.

TSENG, K.C., CHIEN-LUNG, H. \& YU-HAO, C. 2012. Acceptance of information technology and the internet by people aged over fifty in Taiwan. Social Behavior \& Personality: An International Journal, 40(4):613-622.

VENKATESH, V. 2000. Determinants of perceived ease of use: Integrating control, intrinsic motivation, and emotion into the Technology Acceptance Model. Information Systems Research, 11(4):342-365.

VENKATESH, V., BROWN, S.A., MARUPING, L.M. \& BALA, H. 2008. Predicting different conceptualisations of system use: The competing roles of behavioral intention, facilitating conditions, and behavioral expectation. MIS Quarterly, 32(3):483-502.

VENKATESH, V. \& MORRIS, M.G. 2000. Why don't men ever stop to ask for directions? Gender, social influence, and their role in technology acceptance and usage behavior. MIS Quarterly, 24(1):115-139.

VENKATESH, V., MORRIS, M.G., DAVIS, G.B. \& DAVIS, F.D. 2003. User acceptance of information technology: Toward a unified view. MIS Quarterly, 27(3):425-478.

VENKATESH, V., SPEIER, C. \& MORRIS, M.G. 2002. User acceptance enablers in individual decision making about technology: Toward an integrated model. Decision Sciences, 33(2):297-316.

VENKATESH, V., THONG, J. \& XU, X. 2012. Consumer acceptance and use of information technology: Extending the unified theory of acceptance and use of technology. MIS quarterly, 36(1):157-178. 
WANG, Y.-S. \& WANG, H.-Y. 2008. Developing and validating an instrument for measuring mobile computing self-efficacy. Cyber Psychology \& Behavior, 11(4):405-413.

YOUSAFZAI, S., PALLISTER, J. \& FOXALL, G. 2009. Multi-dimensional role of trust in internet banking adoption. The Service Industries Journal, 29(5):591-605.

ZHANG, X. \& ZHANG, Q. 2005. Online trust forming mechanism: Approaches of an integrated model. ICEC'05, 15-17 August, Xi'an, China.

ZHAO, A.L., KOENIG-LEWIS, N., HANMER-LLOYD, S. \& WARD, P. 2010. Adoption of internet banking services in China: Is it all about trust? International Journal of Bank Marketing, 28(1):7-26.

\section{Appendix 1: Scales}

Perceived ease of use of internet banking (Davis, 1989; Lee, 2009)

IBEOU1 Learning to use internet banking is easy

IBEOU2 Using internet banking does not require a lot of mental effort

IBEOU3 It is easy to use internet banking to do banking transactions

IBEOU4 It is easy to become skilful at using internet banking

Perceived trust in internet banking (Gu, Lee \& Suh, 2009; Lee \& Chung, 2009)

IBT1 Internet banking is trustworthy

IBT2 Internet banking keeps its promises and commitments

IBT3 Internet banking serves the present and future interests of users

IBT4 Overall, I trust internet banking

Perceived convenience of internet banking (Liao \& Cheung, 2002; Torkzadeh \& Van Dyke, 2002)

IBCON1 Internet banking is convenient, because I can do banking activities from a place (like home or office) convenient for me

IBCON2 Internet banking is convenient, because I can do banking activities any time of the day

IBCON3 Internet banking is convenient, because it minimizes the effort in doing banking transactions

IBCON4 Overall, internet banking is more convenient than other available modes of selfservice banking

Perceived time saving of internet banking (Torkzadeh \& Van Dyke, 2002 and theory)

IBTS1 Internet banking minimizes the time I spend doing banking transactions

IBTS2 Internet banking minimizes my queuing time in the bank or to pay accounts at retailers

IBTS3 Internet banking saves me time since I do not always have to go to the bank to do banking transactions

IBTS4 Internet banking minimizes the time pressure when doing banking transactions

IBTS5 Overall, internet banking saves me time

Perceived internet banking self-efficacy (Tan \& Teo, 2000; Wang \& Wang, 2008)

IBSE1 I am confident of using internet banking even if I have only the online instructions for reference

IBSE2 I am confident of using internet banking even if there is no one around to show me how to do it

IBSE3 I am confident of using internet banking even if I have just the online "help" function for assistance 
IBSE4 I am confident in using internet banking if I have sufficient time to complete the transactions

Internet banking facilitating conditions (Shih \& Fang, 2004; Venkatesh, Morris, Davis \& Davis, 2003)

IBFC1 Throughout every day of the week I have access to a computer that I can use for internet banking

IBFC2 I have the time to use internet banking

IBFC3 I have the money to use internet banking

Perceived risk of internet banking (Featherman \& Pavlou, 2003; Kim, Prabhakar \& Park, 2009)

IBR1 Considering the possibility of monetary loss associated with internet banking, how risky do you consider internet banking to be?

IBR2 Considering the possibility of harm to you resulting from the misuse of important personal and financial information due to the use of internet banking, how risky do you consider internet banking to be?

IBR3 Considering the possible loss of privacy because of information collected about you as you use internet banking, how risky do you consider internet banking to be?

IBR4 How risky do you rate internet banking? 